\title{
Humanist Principles Underlying Philosophy of Argument ${ }^{1}$
}

\author{
GEORGE BoGER
}

Canisius College

Résumé: Je fais un compte rendu des réflexions des philosophes importants de l'argumentation pour en dégager les principes qu'ils partagent. Je constate que l'intérêt croissant dans la pragmatique dialogique se rapproche plutôt à l'éthique appliquée qu'à l'épistémologie appliquée. De là je tire des conséquences possibles pour la philosophie de l'argument, et j'encourage d'autres discussions en demandant s'il y a une position implicite morale ou même politique qui est à la base de la philosophie de l'argument.

Keywords: Absolutism, acceptability, argumentation, audience adherence, Cartesian God's-eye-view, context, deliberation, democracy, fallacy, formal logic, freedom, humanism, informal logic, person, persuasion, pragmatics, principles, reasonableness, self-evidence

\section{Introduction: Re-centering on deliberative discourse}

Each of the principal founders of the modern argumentation movement-Chaïm Perelman, Stephen Toulmin, and Charles Hamblin-has repudiated the Cartesian rationalism of traditional logic and each has especially challenged its claim of eternality. Perelman and Lucie Olbrechts-Tyteca write that

the very nature of deliberation and argumentation is opposed to necessity and self-evidence ... we combat uncompromising and irreducible philosophical oppositions presented by all kinds of absolutism. (Perelman \&

Olbrechts-Tyteca 1969: 1)

Perelman here expresses a sentiment that runs throughout his thinking and that might well be taken as a special tenet underpinning his philosophical mission. Toulmin in much the same vein writes that "certainly language as we know it consists, not of timeless propositions, but of utterances dependent in all sorts of ways on the context or occasion on which they were uttered" (1958: 180). This proposition underpins virtually all theoretical discussions in the philosophy of argument. And Hamblin similarly notes that 
the complicated shuffle [in the practice of formal logic] involving the construction of 'alternative' systems disguises the fact that nothing is proved absolutely at all, and that an unpalatable theorem can sometimes be a ground for going back and altering the axioms or rules. (1993: 249)

Each philosopher has challenged the self-enthronement of formal logic_-its having assumed the posture of 'God's eye-view' to establish self-evident principles (axioms) and to deduce absolute truths from those principles. Indeed, these philosophers of argument set the course for many logicians who have taken up their manifesto to rethink argumentation and to have it then address practical matters in the messy world of everyday life where nothing is fixed and permanent. In this connection they surely embrace Aristotelian phronêsis, that excellence consisting in someone's making a good decision from exercising a cultivated ability to deliberate about varying circumstances. Phronêsis, we may recall, is the preeminent excellence relating to both an individual's moral character and a politician's leadership.

Logic, as a discipline assessing arguments, has accordingly been broadened well beyond the impersonal character and timelessness of deductive necessity to include matters traditionally excluded from logic so-called-namely, matters of rhetoric, pragmatics, dialogical dynamics, critical thinking, and communication studies. This seems to recall Aristotle's original plan compassing the treatises in the Organon, and not a few argumentationists acknowledge this. And while there are a variety of trends and lively differences within the argumentation movement, argumentation theorists are generally agreed about the transitory nature of logic as it addresses the transitory nature of the human condition-that very condition, they maintain, that establishes the theater of argumentative discourse. And in just this theater, they also maintain, we cannot expect truth and soundness but must be content to work with what is acceptable and 'reasonable'. In this connection, then, Christopher Tindale, a contemporary argumentation theorist who invokes Perelman's spirit, writes:

Truth ... relates to the determinations of audiences; it is a product of argumentative situations, open to scrutiny and to challenge. To proceed this way is to break with any notion of objective Truth that is the goal and condition of argumentation. Such a notion of Truth demands the cessation of argumentation. (1999: 96)

And Trudy Govier, another contemporary argumentationist, remarks in this connection that

if we move from truth to acceptability and from validity to a variety of less determinate and clearcut standards, we are allowing, in effect, that justification itself is relative to time, place, and background beliefs. (1987: 283)

Just here we encounter a specter of relativism seeming to haunt argumentation studies. This matter has been taken up by philosophers of argument, such as Tindale, Govier, Robert Pinto, and Harvey Siegel, and it continues to be a matter of concerned discussion (cf. Boger 2005b). 
Besides having to address a specter of relativism challenging philosophy of argument because of its turn from truth to acceptability, argumentation theorists have been principally concerned from the outset with the practices involved in arguing. Indeed, concern with formal validity has been virtually supplanted by concern with various rules for managing an argumentative situation. This is especially evident in re-conceiving a fallacy, not as a mistake in reasoning per se but as breaking a rule for reasonable discourse. However, in just this connection a topic not especially addressed by philosophers of argument concerns the principles underlying argumentation theory as such theory is used, implicitly or explicitly, in assessing arguments, indeed, in determining just what an argument is and thus in establishing sets of dialogical rules. ${ }^{2}$

Our discussion investigates whether modern argumentationists hold, contrary it seems to a founding inspiration against eternality, a set of underlying principles not subject to deliberation. It reviews the thinking of some prominent philosophers of argument and then extracts some tenets common to these philosophers that underpin their thinking about argument. By presenting these philosophers own words, this review helps to establish a clear humanist impulse animating philosophers of argument. ${ }^{3}$ Finally, it identifies a principle underscoring much discourse about argumentation. We leave our discussion with an invitation to consider whether philosophers of argument embrace, or ought to embrace, an underlying moral, or even a political, posture because their disposition toward the human condition aims to empower ordinary human beings to become autonomous members of democratic communities.

\section{An initial impulse challenging formal logic}

Informal logicians-and argumentationists generally-early experienced an uneasiness about the efficacy of formal logic for treating matters of everyday life. It is no mystery that their having been impelled in this direction emerged from their encountering classroom frustrations during the 1950s and 1960s, particularly in the United States, that combined (1) recognizing that formal logic textbooks were out of touch with everyday matters-having become preoccupied with formal languages and recursive systems, etc., and, when venturing to treat practical matters, passing on the same examples from edition to edition-with (2) an increasing critical dissatisfaction with consumer society-and especially in this connection with the techniques and damaging effects of advertising — along with (3) an ever sharpening criticism of American foreign and domestic policy in respect of the Viet Nam War and civil rights - and in this connection with the rhetoric of disingenuous political figures. It makes perfect sense that concern with fallacious reasoning held a central place for these logicians. We might now add, among other matters as the argumentation movement has matured, concerns with (4) managing marital disputes fairly as women's issues have become part of public discourse, 
(5) managing contract negotiations between labor and capital, and with (6) ameliorating ethnic tensions in a cause of reconciliation if not of justice.

A cursory glance at argumentation literature reveals the richness of these studies about reasoning and reasonableness and about the richness of their relevance for guiding humanists concerned to address the many politically charged 'conversations' in our modern pluralistic and increasingly global community. There is no mistaking an overarching concern among argumentationists, whatever their theoretical differences, to empower people with capacities to reason critically and to assess incisively the conflicting argumentations that play an important role in the lives of ordinary human beings. As many argumentationists are logic instructors treating informal logic, critical thinking, and the fallacies, they are daily in the trenches and occupy a first line of defense against bad reasoning and, we might add, for promoting the genuine interests of human beings. Christopher Tindale, who elevates his teaching with theoretical reflection, promotes Perelman's notion that "[a]rguers address the whole person, not the isolated intellect or emotion, and they consider as a natural course the circumstances and differences involved" (1999: 201; emphasis added). Moreover, he notes that

a theory of argumentation and its associated notion of reasonableness should contribute to the development of the idea of the human, facilitate an environment in which it can flourish, and promote ends that connect the threads of that project. (1999: 202; emphasis added)

This is not merely a fleeting thought espoused by Tindale and many other argumentation theorists. Tindale, we believe, expresses a foundational humanist impulse animating contemporary argumentationists, the same originating impulse that animated Perelman, Toulmin, and Hamblin, the acknowledged progenitors of the modern argumentation movement. The volume of textbooks on informal logic and critical thinking and their selections of practical, real arguments to exercise a student's newly acquired evaluation skills attest to this concern. A salient theme among argumentation philosophers is promoting the pragmatics of argumentative discourse to broaden and secure a more democratic society. Perelman and OlbrechtsTyteca explicitly state that their new rhetoric aims to fight absolutism in all its forms and to resist totalitarianism (1969: 510).

Now, despite differences among argumentationists participating in the various currents of the argumentation movement, are there, nevertheless, shared tenets about argumentation? And, moreover, is there a common vision concerning the mission or objective of logic as construed by these non-formal, non-traditional logicians?

\section{Some shared tenets among philosophers of argument}

Argumentationists have variously characterized an argument as something practical, substantial, real, and personal. Argumentation, then, is construed as a thoroughly social activity that exists in a natural language and accordingly is something quite 
complex and not especially amenable to the coercive imposition of platonic formalism. Philosophers of argument have made a number of counterproposals to a formalist understanding of an argument as 'a two-part system of propositions that is either valid or invalid independent of context'; formal logicians putatively discount the relevance of context. Thus, for example, we find van Eemeren et al. proposing the following eclectic definition:

Argumentation is a verbal and social activity aimed at increasing (or decreasing) the acceptability of a controversial standpoint for the listener or reader, by putting forward a constellation of propositions intended to justify (or refute) the standpoint before a rational judge. (1996: 5; authors' emphasis)

Johnson, an informal logician, considers an argument to be "an intellectual product, essentially public and social in character, that seeks to persuade rationally" (2000: 24). He also writes, more fully, that an argument is

a type of discourse or text-the distillate of the practice of argumentationin which the arguer seeks to persuade the Other(s) of the truth of a thesis by producing the reasons that support it. In addition to this illative core, an argument possesses a dialectical tier in which the arguer discharges his dialectical obligations. (2000: 168; emphasis added)

And Johnson considers the practice of argumentation in this connection to be a "sociocultural activity of constructing, presenting, and criticizing and revising arguments ... understood within the network of customs, habits, and activities of the broader society that gives birth to it" (2000: 154). ${ }^{4}$ Govier writes that an argument is "a set of claims that a person puts forward in an attempt to show that some further claim is rationally acceptable ... an argument is a reasoned attempt to justify a conclusion" (1988:1; cf. 17). And James Freeman notes that an argument is "a message that attempts to establish a statement as true or worthy of belief on the basis of other statements" (1993: 35; cf. 43). Douglas Walton, enriching informal logic with pragma-dialectics, writes that "in logical pragmatics an argument is a claim that, according to appropriate procedures of reasonable dialogue should be relevant to proving or establishing the arguer's conclusion at issue" (1989: 1; emphasis added). For Walton, dialogue is "a sequence of exchanges of messages or speech acts between two (or more) participants" (1989: 3). And Tindale infuses informal logic with new rhetoric to propose that an

'[a]rgumentation' is the site of an activity, where reasons are given and appraised, where beliefs are recognized and justified, and where personal development is encouraged ... The argumentation at stake here is not, exclusively, the argumentation of academics but the broader domain of persuasive and investigative discourse that arises in the marketplace, in the media, on the internet, and in the everyday conversations of citizens, and that thence may find its way into the academy. (1999: 1; emphasis added)

Those embracing an enduring dissatisfaction with formal logic maintain, in an important respect, that considering an argument's context is an essential component 
of argument appraisal and just as vital for any normative considerations when working with arguments/argumentations in real-life, human situations.

Now, while there are some acknowledged differences among these understandings of what an argument is, there is, nevertheless, general unanimity on a principal purpose of arguing, or making an argument-namely, to persuade or to convince. This is the case whether the situation is a contract negotiation, settling a marital dispute, mediating conflicts between dorm students, composing a scientific, a political, or a moral discourse, etc. Thus, they believe, a formalist's predominant concern with deductive validity is misplaced for having obviated the rhetorical and instrumental dimensions of argumentation. And, more fundamentally, they consider the traditional formalist concern with deductive validity to be misplaced by subscribing to a belief in a possibility of securing objective knowledge-this hope has been exploded by the reality of multiple contexts in a world replete with disparate narratives. This hope has also been diminished by adhering to the putative reality of the relativity of cogency.

Informal logicians and argumentation theorists have not minced words about their complaint with traditional formal logic. Hamblin had exhorted that " $[\mathrm{w}]$ hat is, above all, necessary is to dethrone deduction from its supposed pre-eminent position as a provider of certainty" (1993: 250; emphasis added). ${ }^{5}$ This statement was a 'shot heard round the world' by new logicians that promoted new and fruitful lines of inquiry that continue to be explored today. A review of the original works of the founders of the argumentation movement along with the works of those who have been contributing to argumentation studies since the 1970s reveals a rather uniform set of beliefs underlying the diverse currents of argumentation philosophy. Indeed, recognizing this set of tenets might help to objectify an underlying unity of these currents. In any case, among these tenets we identify the following. ${ }^{6}$

1. Soundness is neither a necessary nor a sufficient condition for a good argument. An argument's goodness turns not on the truth of its premises nor on its formal validity but on the acceptability of its premises and the suitability of its inferential links.

2. The deductive model of a good argument does not properly serve argument evaluation. The distinction between deduction and induction is not only inexact but specious. An argument consists in assertions and statements made by human beings in an imperfect world; it does not consist in atemporal propositions.

3. Arguing is a social activity always embedded situationally and most often expressed by means of a natural language. An argument is something personal, not something impersonal. Thus, using a natural language and being contextually situated, an argument is replete with ambiguity and nuance.

4. Appraising the cogency or reasonableness of an argument requires close attention to its context. Reasonableness is not rationality as 
rationality is traditionally understood to be context-independent. Rather, an argument's cogency is participant- or audience-dependent, and not an objective property inhering in a premise-conclusion argument. Since an argument always exists within a particular context, special attention must be given to assessing premise relevance and the sufficiency of their support for a conclusion.

5. There are no clear demarcations between an arguer, an audience, an argument (a product), an argumentation (a process) that involves an exchange between disputants, procedures for managing those exchanges (dialectic), and an argument's presentation (rhetoric).

Perhaps we might consider these tenets 'axiomatic' of argumentation theory; and surely they are foundational principles underlying argumentation analysis. However, while argumentationists work from these tenets, they might be taken as more metasystematically descriptive of argumentation philosophy. They are, then, secondary (but not derivatively) to a more foundational principle to which we shall return once having reviewed two further matters-(1) an especially poignant criticism of formal logic and (2) a principal concern with dialogical pragmatics running through argumentation textbooks and theoretical discussions.

\section{A special criticism of formal logic}

Argumentationists generally consider formal logic to prefer axiomatic fixedness and to eschew deliberation. In this connection, then, formal logic does not describe reality-least of all does it capture how human beings deliberate. The deductive model, even as a regulative principle, is inadequate and not universally applicable, since not only is its ideal unattainable but also it is not subscribed to by every audience. The Cartesian ideal of deducing truths from foundational self-evident truths is suspect; for, indeed, there are no self-evident, non-controversial truths. Moreover, formal logic eschews ambiguity, requires univocity, and works abstractly with a logically perfect language. However, arguing occurs in a natural language, which is replete with ambiguity, nuance, equivocal expressions, and is not abstractnone of which is amenable to traditional formal analysis. Applying formal rules, then, to extract the propositions expressed by assertions is thought only to distort the original statements.

Here we might recall some passages from prominent proponents on this especially sharp criticism of formal logic's inadequacy. Perelman and Olbrechts-Tyteca write that the new rhetoric

constitutes a break with a concept of reason and reasoning due to Descartes [who made "the self-evident the mark of reason"] which has set its mark on Western philosophy for the last three centuries. ... The very nature of deliberation and argumentation is opposed to necessity and self-evidence, since no one deliberates where the solution is necessary or argues what is self-evident. (1969: 1) 
This seems implicitly to reproduce Aristotle's distinction between the lower and higher faculties of the rational part of a human soul-logistikon, or the faculty for calculating and deliberating about what can be otherwise, and epistemonikon, that faculty for contemplating eternal principles. Perelman has also sharply stated this notion elsewhere.

Take away the guarantee which God gives to self-evidence and, suddenly, all thought becomes human and fallible, and no longer sheltered from controversy. ... But lacking self-evidence that can be imposed on everyone, a hypothesis, to be accepted, must be supported by good reasons, recognized as such by other people, members of the same scientific community. The status of knowledge thus ceases to be impersonal because every scientific thought becomes a human one, i.e., fallible, situated in and subjected to controversy. (Perelman 1982: 159; cf. 24; emphases added) ${ }^{7}$

Surely this recalls the humanist thinking of the Enlightenment about the selfmovement of human beings who ought to rely upon human reason for solving human problems - an underlying principle of democratic philosophy. Toulmin has complemented in various places what Perelman and Olbrechts-Tyteca have stated:

[In respect of soundness in predictive arguments] if validity is to be a timeless 'logical relation' between the statements alone, facts about their occasion of utterance must be swept aside as irrelevant. ... [the formal logician] looking down from his Olympian throne ... sets himself to pronounce about the unchangeable relations between them. But taking this kind of God's-eyeview distracts one completely from the practical problems out of which the question of validity itself springs. ... Questions about the acceptability [or soundness] of arguments have in practice to be understood and tackled in a context quite as much as questions about the acceptability of individual utterances, and this practical necessity the purely formal logician strikes out of the account before even beginning his work. (1958: 184-185)

And Hamblin, in much the same vein, comments (1993: 249; cf. 251) that a formal proof "far from setting a high standard of argument-worth for us, completely lets slip certain important desiderata". The sin of formal logic consists in its blatant disregard for, its sometimes intentional motivation to disguise, the fact that nothing is proved absolutely at all. Passages such as these, and there are many of them running throughout argumentation literature, show that philosophers of argument, besides challenging deductivism, are inescapably humanists in the best of the ancient and modern humanist traditions. They aim to empower ordinary human beings whom they consider to have been victimized by self-proclaimed authorities of any formalism that threatens their autonomy.

In another and related respect argumentationists have remarked that formal logic focuses on rationality rather than on reasonableness. Formal logic has concentrated on a model of Cartesian rationality that has been proffered as universal, objective, absolute, and atemporal-it has diminished the importance of reasonableness, which is especially contextual. However, since this platonic realm remains forever beyond human reach, humans are left with having to make 
reasonable decisions based on available evidence. Perelman and Olbrechts-Tyteca write:

It is the idea of self-evidence as characteristic of reason, which we must assail, if we are to make place for a theory of argumentation that will acknowledge the use of reason in directing our own actions and influencing those of others. (1969: 3)

The assertion that whatever is not objectively and indisputably valid belongs to the realm of the arbitrary and subjective creates an unbridgeable gulf between theoretical knowledge, which alone is rational, and action, for which motivations would be wholly irrational. (1969: 512)

Toulmin, in this connection poignantly critical, calls for a 'return to reason', and he especially aims to dethrone the Cartesian imperial rationality with egalitarian reasonableness (2001: 21-22, 156-157; cf. 204). The one-theoretical argumentis formal, abstract and general, empty, context-free, platonically pure and timeless, and value-neutral; the other-factual narrative-is substantive, timely, practical and local, empirical, situation-dependent, and everyday and morally loaded (2001: 24). Again, the one is desituated or disembedded, the other situated or embedded (2001: 26). In addition, Toulmin's social history of logic locates the split between the reasonable and the rational in the Peace of Westphalia, out of which came absolute sovereignty, established religion, and logical demonstration, all of which share two common features: "[1] all of them operated top-down, and gave power to oligarchies-political, ecclesiastical, or academic-that supported one another ... [2] they formed a single [ideological] package" (2001: 156). Toulmin also writes that " $[\mathrm{t}] \mathrm{he}$ Westphalian Settlement was, then, a poisoned chalice: intellectual dogmatism, political chauvinism, and sectarian religion formed a blend whose influence lasted into the twentieth century" (2001: 158). He then remarks about the contemporary world:

As in politics, tolerance and democracy are winning out over elitism in methodology, and over imperialism in the philosophy of science. To that extent, the imbalance in European ideas about Rationality and Reasonableness shows healthy signs of correcting itself. (2001: 167)

And Hamblin, from much the same sensibility, has similarly observed that a liberating turn of developments affirms the self-determination of the individual thinker/citizen against trying to step outside and adjudicate.

[W] have no basis other than our own [frames of reference] on which to do so. Truth and validity are onlookers' concepts and presuppose a God's eyeview of the arena. ... [onlookers might intervene and thus] become simply another participant in an enlarged dialectical situation and that the words 'true' and 'valid' have become, for [the participant] too, empty stylistic excrescences. To another onlooker, my statement that so-and-so is true is simply a statement of what I accept. (1993: 242-243)

Hamblin emphatically remarks that this point "is of fundamental philosophical importance" (1993: 243). ${ }^{9}$ Here again, as with Toulmin and Perelman, we observe a special humanist concern to diminish dogmatism, to dispel all explicit and implicit 
forms of domination, and, in this connection, decidedly to promote deliberation and the free exchange of ideas.

Were we to identify a political platform upon which these philosophers might stand, we can readily cite the $18^{\text {th }}$ century American and French declarations of freedom, notwithstanding their Enlightenment ontology. From the American Declaration of Independence (4 ${ }^{\text {th }}$ July 1776) we find this dialogic principle - " $a$ decent Respect to the Opinions of Mankind requires that they should declare the causes which impel them to the Separation" in the course of human events leading to the dissolution of political tyranny and the establishment of a more perfect union. Against a tyranny such as Toulmin cited, we further read:

We hold these Truths to be self-evident, that all Men are created equal, that they are endowed by their Creator with certain unalienable Rights, that among these are Life, Liberty and the Pursuit of Happiness-That to secure these Rights, Governments are instituted among Men, deriving their just Powers from the Consent of the Governed, that whenever any Form of Government becomes destructive of these Ends, it is the Right of the People to alter or to abolish it, and to institute new Government, laying its Foundation on such Principles, and organizing its Powers in such Form, as to them shall seem most likely to effect their Safety and Happiness. .... But when a long Train of Abuses and Usurpations, pursuing invariably the same Object, evinces a Design to reduce them under absolute Despotism, it is their Right, it is their Duty, to throw off such Government, and to provide new Guards for their future Security. ${ }^{10}$

And, springing from the same inspiration and using similar language, the French Declaration of the Rights of Man (27 $7^{\text {th }}$ August 1789; translated by James Harvey Robinson) affirms the rights of the citizen to freedoms untrammeled by despotic and alien authority. Among its 17 articles are the following.

Article 1. Men are born and remain free and equal in rights. Social distinctions may only be founded upon the general good.

Article 10. No one shall be disquieted on account of his opinions, including his religious views, provided their manifestation does not disturb the public order established by law.

Article 11. The free communication of ideas and opinions is one of the most precious of the rights of man. Every citizen may, accordingly, speak, write and print with freedom, but shall be responsible for such abuses of this freedom as shall be defined by law.

These Enlightenment expressions of humanist philosophy haunt argumentationists' overarching concern with the human. Before considering this topic further we turn briefly to treat a second matter quite familiar to argumentationists, which matter resonates with the principles expressed in these two documents. 


\section{A concern with dialogical pragmatics}

Evaluating the informal fallacies occupied considerable attention at the outset of the argumentation movement some 25 years ago, and logicians continue to examine these fallacies with fruitful results. An important consequence is recognizing the complexity of human reasoning. Having now come especially to appreciate the contextual relativity of cogency, of inferential links, even of 'truth' and 'falsity' in connection with gaining audience adherence-all putatively the bane of formal logic - argumentation logicians have recalled something of the ancient and medieval, even renaissance, notions of rhetoric and the pragmatics of discourse. Since these logicians consider argumentation to be a natural and inescapable aspect of human lived experience, and since, moreover, they consider formal logic to have stripped such lived experience of its dynamism and to have rendered logic irrelevant because of its static nature, philosophers of argument have aimed to 'materialize' logic. However, they might also be thought to subscribe to the following proposition'If we cannot establish truth, if we cannot establish who is right who wrong, if we must shift from objectivity to acceptability, then we must turn to what remains in the arena of human beings arguing/persuading/convincing one another.' This, of course, in one important respect, immediately requires considering the pragmatics of discourse, or, that is, rules for managing an argumentative discussion, which many logicians agree is foundationally dialogical. And so, following the lead of the earliest proponents and responding to their own senses of what is right, many argumentation logicians are now treating the dialogical and pragmatic matters of argumentative discourse. ${ }^{11}$ Argumentationists, then, tend forcefully to dismiss formal logic's putatively myopic concern with formal, or deductive, validity to re-center logic's focus on acceptability away from truth, on participant-determined cogency away from objective principles of implication, on the relativity of varying narratives away from an absolutist 'federalism' of objective principles-for, after all, any given argument exists inextricably in a given context and is meaningful only in that given context. And, besides, formal logicians have failed to formalize fallacious reasoning and to devise a formal method for establishing knowledge of invalidity.

With a turn from embracing a traditional purpose of argumentation as establishing truth using formal logic instrumentally to convincing an audience, or establishing audience adherence, many argumentation logicians have generally veered from a concern with establishing objective knowledge-for, from one important posture, the universal audience is a fiction, at best a kantian regulative principle, and this leaves the thing-itself forever unknowable. Perhaps the argumentation movement is a part of a larger post-modern hermeneutics project. In any case, these logicians have now taken up a principal concern with the dynamics of argumentation, with the theater of argumentative discourse, and as a consequence have come to embrace another, different concern with form (Barth $\&$ Krabbe 1982). And here matters rhetorical and pragmatic, employed toward an agreed upon social end, again trump truth. 
Our concern here is to plumb some argumentationists' thinking to identify a set of principles underlying their reflections on argument in respect of concern with dialogical pragmatics. This, of course, is a large project that requires a fuller examination than we can provide in this discussion. Still, we can provide a more sweeping overview by presenting some prominent logicians who treat pragmatic matters, while generally embracing the tenets identified above ( $(3)$, and who traverse various currents of the argumentation movement-Van Eemeren from the pragmadialectic speech-act current, Walton from the dialogical current, Johnson and David Hitchcock from informal logic. This list hardly aims at completeness but at drawing attention to a significant trend shared by many argumentation theorists notwithstanding their important differences. The remainder of this section highlights some of the salient thinking about argumentation that indicates deep-seated humanist concerns running throughout, or underpinning, philosophy of argument.

Frans van Eemeren and Rob Grootendorst. Van Eemeren and Grootendorst had long worked together to draft a set of rules governing argumentative discourse. Perhaps their thinking is best portrayed in their consideration of fallacies. Breaking from the traditional notion that a fallacy is 'an argument that seems valid but is not', or even 'a reasoning that is deductively invalid', they shift the notion to argumentative practices-a fallacy now becomes 'an incorrect discussion move in which a discussion rule has been violated' (1992: 104).

Van Eemeren and Grootendorst present "an ideal model in which the rules for reasonable argumentative discourse are specified as rules for the performance of speech acts in a critical discussion aimed at resolving a dispute" (1992:104). They, of course, are careful "not to exaggerate the role of [formal] logic" (1992:103). Here we list the ten rules they extract for governing critical discussion (1992:208209).

Rule 1: Parties must not prevent each other from advancing standpoints or casting doubt on standpoints.

Rule 2: A party that advances a standpoint is obliged to defend it if the other party asks him to do so.

Rule 3: A party's attack on a standpoint must relate to the standpoint that has indeed been advanced by the other party.

Rule 4: $\quad$ A party may defend his standpoint only by advancing argumentation relating to that standpoint.

Rule 5: A party may not falsely present something as a premise that has been left unexpressed by the other party or deny a premise that he himself has left implicit.

Rule 6: $\quad$ A party may not falsely present a premise as an accepted starting point nor deny a premise representing an accepted starting point. 
Rule 7: $\quad$ A party may not regard a standpoint as conclusively defended if the defense does not take place by means of an appropriate argumentation scheme that is correctly applied.

Rule 8: $\quad$ In his argumentation a party may only use arguments that are logically valid or capable of being validated by making explicit one or more unexpressed premises.

Rule 9: $\quad$ A failed defense of a standpoint must result in the party that put forward the standpoint retracting it and a conclusive defense in the other party retracting his doubt about the standpoint.

Rule 10: A party must not use formulations that are insufficiently clear or confusingly ambiguous and he must interpret the other party's formulations as carefully and accurately as possible.

These authors elsewhere cite the Principle of Communication aimed to assure that participants when communicating with each other by means of reasoned discourse observe the four standards of clarity, honesty, efficiency, and relevance (1996: 12). Their notion of a fallacy as "[a]ny violation of any of the rules of the code of conduct for rational discussants (by whichever party at whichever stage of the discussion)" (1984: 189; emphasis added) makes perfect sense in this framework.

Douglas Walton. Walton in his discussion of begging the question embraces the work of van Eemeren and Grootendorst and distinguishes two types of fallacy(1) a sophistical tactic and (2) an error of reasoning. Since the error of reasoning type of fallacy "involves no essential reference to a context of dialogue", he directs attention to the sophistical tactic type that is "a deceptive tactic used by a participant in argumentative dialogue to block or frustrate the legitimate goals of the dialogue by breaking or subverting the rules" (1991: 215).

Now, recognizing that many fallacies do not involve deductive invalidity (and here he considers begging the question to be just such a fallacy), Walton notes (1991: 216) that such faults in argumentative dialogue might include the following:

1. Failure to state or stick to an issue in argumentation;

2. Failure to document sources of expert onions cited;

3. Failure to ask reasonable and appropriate questions in a discussion;

4. Use of emotional appeal to avoid argument, or to try to close off argument prematurely;

5. Prejudicial use of unclear terms that may be vague or ambiguous. He indicates the existence of other faults and re-emphasizes his notion that fallacies "most often appear to be violations of rules of reasonable dialogue appropriate to a given social context or argumentative discussion" (1991: 217). And while acknowledging the advance made by van Eemeren and Grootendorst in formulating 
a pragmatic conception of fallacy as a violation of a normative rule of dialogue, he considers a fallacy to be more than just a violation of a rule of reasonable dialogue while not necessarily involving an intention to deceive (1991: 217, 218, 224). Walton then proposes that a fallacy is

[a] move, or sequence of moves, in an argumentative discussion ... if it breaks some rule of dialogue to the advantage of its proponent, evidently as part of a larger strategy to get the best of the opponent (unfairly). (1991: 218; emphasis added)

Thus, in being more than a faulty argument, a fallacy, according to Walton invoking Aristotle, is "an unfair verbal tactic of defeat in contestive argumentation" in a dialogue game (1991: 219; emphasis added). And just in invoking Aristotle Walton remarks that rescuing Aristotle's dialectic is worth the effort "as a methodology underlying the humanities", however much this requires a reevaluation of reasoning. Just here he develops the notion of a dialogue game. Dismissing the error of reasoning kind of fallacy as monolectic and falling under formal considerations of deductive validity, Walton more specifically refines his notion of a fallacy as a sophistical tactic in this way-it refers:

to the use of a trick or deceit used in argument by one party in a dialogue unfairly to get the best of, or defeat the other party. ... The sophistical tactic type of fallacy is a dialectical fault - it requires an interactive exchange where one participant leads the other participant to draw a wrong conclusion in order to take advantage of this error to gain a victory in the exchange. (1991: 219; emphasis added)

Walton and Krabbe in Commitment in Dialogue (1995) have also extensively treated the matter of developing dialectic, or dialogical, rules, having taken their lead especially from Hamblin's concept of argument and his discussion of formal dialectic (1993). ${ }^{12}$ Our concern asks what motivates Walton and Krabbe, and, indeed, the others as well, to select just these rules.

Ralph Johnson and David Hitchcock. Johnson devotes considerable attention to elucidating his notion of manifest rationality, part of which is recognizing an argument to have both an illative core and a dialectical tier. The dialectical tier, of course, is the pragmatic aspect of an argumentation, since an argument aims at rational persuasion (2000: 150). The illative core of a good argument consists in premises that are acceptable, true, relevant, and sufficient (2000: 190-206), which Johnson considers to be necessary conditions. He recognizes that acceptability and truth might conflict (2000: 191) and then asserts that truth trumps acceptability because it better accords with his concept of manifest rationality (2000: 337; Johnson refers this matter to the "Integration Problem" (2000: 336-340)). However, when we inquire just what manifest rationality is, we find Johnson writes that not only that a good argument is itself a rational product-a product of reasons, reasoning, and reasoners-but that it is a part of the nature of the enterprise that this product must appear to be rational as well. (2000: 144; cf. 163-164; emphasis added). 
Later he writes that " $[\mathrm{t}] \mathrm{his}$ additional consideration, this clothing of rationality, is what makes argumentation more than just an exercise in rationality" (2000: 163; emphasis added). And here we now discover that acceptability trumps truth. Johnson must surely be aware, at least implicitly, of this problem, for he regularly places restraints on the participants in an argumentation. ${ }^{13}$

By rational persuasion, I mean that the arguer wishes to persuade the Other to accept the conclusion on the basis of the reasons and considerations cited, and those alone. In entering the realm of argumentation, the arguer agrees to forswear all other methods that might be used to achieve this: force, flattery, trickery, and so forth. (2000: 150; emphasis added)

Johnson also remarks that "[m]anifest rationality is why the arguer is obligated to respond to objections and criticisms from others and not ignore them or sweep them under the carpet" (2000: 163-164; emphasis added). Later we read that "[a]n absolute precondition of this practice is the assumption of good will: that people giving children treats would do just that" (2000: 212; emphasis added).

Hitchcock (2002) nicely complements Johnson's discussion of argumentation by modifying his notions of argument and argumentation. ${ }^{14}$ In short, Hitchcock drops 'truth' for 'acceptance' in the case of argument, and in the case of argumentation, he follows van Eemeren and Walton to use 'argumentative discussion' rather than 'argumentation' and thus focuses on characterizing the purpose of participants rather than the function of the practice- the purpose, then, is now described as "reaching a shared rationally supported position on some issue" rather than 'persuasion'.

Without treating ensuing discussion between Hitchcock and Johnson, we take liberty to cite Hitchcock (in full) as agreeably developing Johnson's thinking by diminishing its rhetorical posture. Be that as it may, we are more interested here to consider Hitchcock's derivations, following the spirit of Johnson's discussion, of the characteristics of argumentative discussion. ${ }^{15}$ Consider the following 17 theorems that Hitchcock identifies.

Theorem 1: Aparticipant in argumentative discussion who makes a claim which requires rational support must support it with reasons.

Theorem 2: Participants in an argumentative discussion may appeal to reasons (including physical evidence) and only to reasons.

Theorem 3: A participant may not resort to trickery or force to get a claim accepted.

Theorem 4: An argumentative discussion presupposes a background of controversy (or potential controversy) about the issue under discussion.

Theorem 5: The author of an argument in an argumentative discussion has a responsibility to deal with known alternative positions and with known objections.

Theorem 6: The addressees of an argument in an argumentative discussion have a responsibility to provide criticism of that 
argument if they believe it warranted, and the arguer has a responsibility to welcome and deal with their criticisms. The arguer agrees to let feedback from the Other affect the product, to take criticism seriously; intervention of the Other is not just accepted, but is encouraged, so as to make the product better.

Theorem 7: Contributions to an argumentative discussion must not only be rational, but must be seen by the participants to be rational.

Theorem 8: The outcome of an argumentative discussion is to be determined only by the strength of the better reason.

Theorem 9: Participants in an argumentative discussion must be rational, and must know that they are rational.

Theorem 10: The participants in an argumentative discussion embrace, endorse and cherish rationality.

Theorem 11: An internal good of argumentative discussions is an increase in rationality among the participants and thus an increase in rationality in the world.

Theorem 12: Argumentative discussion depends on a specifically human form of rationality.

Theorem 13: Argumentative discussion is not the only rational process.

Theorem 14: A culture has a practice of argumentative discussion only if its members have a common interest in inquiry, getting at the truth or persuasion.

Theorem 15: A culture has a practice of argumentative discussion only if its members seriously disagree about some important issues (as opposed for example to subscribing jointly so some mythopoetic standpoint).

Theorem 16: A culture has a practice of argumentative discussion only if its members understand and value rationality as a means of achieving their common interest.

Theorem 17: A culture has a practice of argumentative discussion only if its members are open to changing their view as a result of argument.

Hitchcock concludes his revisions of Johnson's concern with manifest rationality by seconding Johnson's remark that argumentative discussion is "an extremely powerful and valuable cultural practice" (2000: 11). He then makes the follow remark.

$[\mathrm{F}] \mathrm{ew}$ other practices, to change ignorance into knowledge and prejudice into reasoned judgement ... [have such] an impact for good. Human wellbeing (and the well-being of animals, species, the biosphere and our planet) is served best by positions and policies which reason would support. ... 
Free and open rational discussion, welcoming criticism and willing to change in the light of that criticism, is the most secure route to correct views and wise policies. (2002: 20; emphasis added)

The above passages from Van Eemeren, Walton, Johnson and Hitchcock provide only a small sampling, nevertheless strongly representative, of how argumentationists treat the pragmatics of argumentative discourse. These citations could be multiplied many times over to illustrate their conviction to embrace a humanist theme in their philosophical deliberations.

We close this section with the reflections of two prominent argumentationists on a deeper interest of philosophy of argument that exemplifies the humanist impulse continuing to animate developments in philosophy of argument.

Addressing the monolithic violence of imperial rationality, Tindale, again invoking Perelman, makes manifest a deep-running sentiment among argumentationists that we readily observe in the above citations about good argumentation. In addressing adherence, he writes:

Adherence is sought through understanding, and this is pursued through the creation of an argumentative environment in which the arguer and audience complete the argument as equal partners. On this model, an audience is not aggressively persuaded by the arguer, but is persuaded by its own understanding of the reasoning.

The suggestion of manipulation thus conflicts with the notion of reasonableness that has been advocated throughout [this discussion] ... Again, what polices an audience's susceptibility to vagueness is the underlying reasonableness captured in the universal audience for that particular audience. If argumentation as an activity is to have credence, then there must be a sense of reasonableness at work. All audiences have such a sense. The exercise of audience construction is important as an exercise even if it is not always successful. We attempt to uncover that working notion of reasonableness alive in any audience and to speak to it. As such, the primary attitude with which audiences are approached is one of respect. (1991: 206; emphases added)

What Tindale writes here connects well with a theme virtually running throughout Govier's writing as a philosopher of argument concerned about human well-being.

In treating rational discussion as having a "socio-personal element" (1987: 277), Govier considers credibility and honesty, trust and sincerity, hallmarks of the ideal practice of argument. She thus construes the purpose of persons engaged in argumentative exchanges

to communicate information, beliefs, and opinions both in order to persuade others by reasons that their beliefs and opinions are true or acceptable and in order to check and possibly revise their own beliefs and opinions as a result of rational criticism and evaluation. (1987: 278)

Govier's thinking is well expressed in an article where she takes up a challenge by a feminist about the 'uselessness' of logic because of its putative male-dominating and confrontational character. There she understands that rational persuasion is: 
persuasion by considerations that affect the assent of another person by supplying evidence or grounds that make a claim seem more believable because of a cogent connection between the claim and the claims cited as its support. (1999: 45-46)

She immediately remarks that "[r] ational persuasion is not coercive" (1999: 46) and continues to note that an argument ought not be manipulative, tricky, or deceptive (1999: 48, 50). Perhaps her thinking is best expressed in the following passage.

To offer an argument for a claim is to show sensitivity to the thinking of other people and a respect for the minds and intellectual autonomy of those addressed in the actual or potential audience. To argue well, one must consider the beliefs, values, and interests of the audience when constructing the argument. An arguer, in actually or potentially addressing those who differ, is committed to the recognition that people may think differently and that what they think and why they think it matters. In this way, to offer arguments may be deemed to show respect for other minds. (1999: 50; emphasis added $)^{16}$

Govier challenges a militaristic characterization of argument as necessarily confrontational, but embraces difference and controversy as, after all, an inescapable part of lived-experience, and recognizes the role of argumentation in a pluralistic society. Govier's thinking here resonates throughout argumentation literature.

\section{A principal tenet underlying argumentation philosophy}

It is commonly appreciated that argumentative situations might be cordial in a mutual concern for an agreeable resolution. However, quite frequently, perhaps more frequently than not, an argumentative situation might have strong eristic and contentious dimensions. This matter is no stranger to argumentationists taking up the pragmatics of argumentative discourse. Indeed, with (1) a shift from taking fallacies, the so-called informal fallacies, to be mistakes in reasoning to shifts in kinds of dialogue or violations of discussion rules and (2) a shift from concern with objective truth to the relativity of cogency and acceptability, we might easily grasp a central concern among argumentationists now with formal discussion rules for managing various kinds of discourse. And in this connection, we can recognize a special concern to construct discussion rules, for example, for mediation, negotiation, or persuasion, and for managing interpersonal interactions. In just such situations contending participants might easily run afoul of reasonableness to give expression to their deep-seated feelings and particularist interests that are disruptive of an amenable resolution to differences of opinion thus, a code (or codes) of conduct seems warranted to manage difficult situations.

We have identified some tenets of argumentation philosophy that bear on descriptive characteristics of argumentation and others that relate more directly to acts of arguing, to the interpersonal dynamic and dialogical dimension of argumentation. We find it particularly interesting to consider how logicians discuss argumentation in respect of their characterizing the participants in good 
argumentation. In this connection, we find a number of salient humanist moral principles to lie at the foundation of their thinking. Consider the following notions that regularly appear in their discussions, as we hope we have indicated with the various texts cited above.

1. Argumentation opposes all kinds of philosophical absolutisms and promotes free and open rational deliberation in modern democratic, pluralistic society. Argumentation is egalitarian, opposing a topdown method of persuasion.

2. Argumentation is associated with a notion of reasonableness that recognizes the relativity of diverse human experiences. Participants embrace, endorse, and cherish rationality, an especial human faculty.

3. Argumentation recognizes that all thought is human thought, that knowledge is not impersonal but personal. Argumentation encourages personal development.

4. An absolute precondition of argumentative practice is the assumption of good will. Argumentation recognizes the personhood of the other; participants respect other minds and their beliefs.

5. Argumentation, in promoting the free exchange of ideas, recognizes the necessity to regulate argumentative discussion by means of dialogical rules that result from the various wills of participants. Participant obligations and responsibilities to abide the rules arise from a duty to respect the person of the Other.

6. Argumentation promotes the values of acting fairly, justly, honestly, and sharing; acting so as not to take advantage of a situation unfairly for the benefit of the one and the harm of the other. Participants eschew the use of prejudice and thoughtlessness. Participants forswear the use of force, flattery, trickery, deception, baneful use of the informal fallacies and illicit dialogue shifts.

7. Argumentative discussion aims to change ignorance to knowledge, prejudice into reasoned judgment, to promote human well-being as much as these may be hoped for. This is especially important since knowledge and beliefs aim at practical implementations that affect the well-being of the community of human beings. Argumentation promotes the idea of the human.

This list, while perhaps incomplete, is sufficiently compassing to establish what philosophers of argument, or non-formalists in counter-distinction to traditional formalists, consider to be the essential purpose of argument-namely, the promotion and betterment of human beings.

From the start argumentationists have resolutely affirmed that argumentation is an especially human activity, indeed, a social activity, involving real persons with real interests, foibles, etc. In addition, they have affirmed in their writings, at least implicitly, an abiding humanist concern with justice and moral sensibility. And so, 
we might affirm with confidence that the axiom underpinning argumentation philosophy is, borrowing its expression from Immanuel Kant, the following"rational nature exists as an end in itself". ${ }^{17}$ This principle distinguishes person from thing as existing for itself, having all its value in-itself, while a thing strictly speaking has only instrumental value, a value relative to something other than itself. Whether we deduce from this axiom the practical imperative, and whether we modify that imperative somehow to accommodate utility (and leaving aside whether other than human beings possess moral standing), we nevertheless can recognize this principle to underlie a moral imperative, more commonly expressed as the Golden Rule, that itself underlies all the specific practical imperatives that arise during theorizing about the pragmatics of argumentative discussion. Indeed, all seven principles cited above are deducible (with appropriate background accounted for) from this principle; and philosophers of argument might well argue their inviolability. Granting this, then, we might rather think of informal logic, or any of the non-formal currents within the argumentation movement, not to be applied epistemology as some would have it, but more appropriately placed under applied ethics than strictly speaking within a realm of logic.

\section{Concluding remarks}

When informal and other non-formal logicians turn from soundness, truth, and deductive validity to acceptability and participant relative notions of cogency and inferential links, they inescapably take up matters relating in the theater of argumentation to dialogical pragmatics. This has become a core concern. And this concern, as we have seen, especially embraces respecting persons in the various arenas of argumentative discussion. In this connection, then, philosophers of argument treat moral matters almost exclusively; and in this connection their humanist predisposition is revealed by the rules they prescribe. In effect, they deduce practical imperatives - to wit, rules - from their principle of the foundational moral worth of the human person. Consequent actions are subsequently deduced from these rules, which also provide normative criteria relating to 'faults' in argumentation. Surely they do not consider this principle subject to deliberation (while who counts as a person, or has moral standing, has been and will unfortunately continue to be discussed). In this way, moreover, informal logics have a metaphysical underpinning, at least, were their proponents following Kant's lead, which seems the case in many respects.

Perhaps examining their metaphysic might be on the argumentationist agenda. Be that as it may, we close with what might be a more pressing matter, just in connection with the concern for justice that initially animated the argumentation movement and that, we believe, still haunts its deliberations. Taking the principle that 'a person exists above all market price' to underpin argumentationist philosophy, we ask whether the following contradiction is meaningful or problematic for philosophers of argument. 
On the one hand, our moral value system is horizontal in recognizing each person to have an absolute moral standing foundationally equal to each other person; it thereby promotes each person's happiness in respect of his/her mental and physical health as well as the enrichment of his/ her intellectual, spiritual, and aesthetic life (as commensurate with being an end).

On the other hand, our market value system is vertical in that it imposes a hierarchy of use-values, or market prices of labor, onto each person; it thereby eclipses moral equality to create a hierarchic system of moral values precisely in respect of each person's ability to purchase in the marketplace those commodities necessary for the mental and physical health as well as for the intellectual, spiritual, and aesthetic enrichment of him/herself and his/her family — in practice some persons are morally worth more than other persons.

Now, given that argumentationists embrace the inviolate worth of persons, do they also then reject an economic/political system that subverts precisely the value of persons in respect of the real possibilities of their personhood fulfillment? Or is the principle of personhood debatable after all? And were it not, are there certain propositions that are necessary consequences that, translated into action, require a significant challenge to the hierarchy of human values inherent in our present market society? A fear we have is that the very rules emerging among the dialogical and pragmatic argumentation philosophers have become as retrogressively formal and thus destructive of their humanist objectives of empowerment and justice as they believe had become the deductivism they challenged. Is the next step among argumentationists impelled by deep humanist convictions to further 'materialize logic' by treating the actual content of arguments and not merely to recognize that formally managing argumentative discourse is important? Is truth the antidote to formalism?

\section{Notes}

${ }^{1}$ An earlier version of this paper was presented at the 2005 OSSA conference at McMaster University - critical remarks from conference participants contributed to its improvement. The discussion benefited considerably by the careful evaluations of two referees. Finally, I am especially grateful to Ralph Johnson for his helpful comments and continuing encouragement.

${ }^{2}$ While differences exist among informal logicians, pragma-dialecticians, communication theorists, dialogue logicians, and rhetoricians, they nevertheless share a core of tenets (see below §3). We use 'argumentationist' or 'argumentation theorist' and 'philosopher of argument' to denote a logician who generally subscribes to this core of tenets within the argumentation movement. Our discussion, then, does not compass all trends of $20^{\text {th }}$ century argumentation studies, for example, that of Arne Naess and the tradition of semantics that now uses argumentation in critical discourse analysis. Rather we focus on a core of philosophers of argument who define an important trend within argumentation studies. 
3 'Humanism' is generalized here to range over various humanisms, such as, secular humanism, religious, scientific, or naturalistic humanism and their individual philosophic expressions, all of which might be traced to their renaissance inspiration and all of which have deep moral convictions. We take humanists, then, to affirm the dignity and worth of human beings and to promote human freedom, especially in the self-determination of individuals and their communities. Besides promoting freedom, humanists promote a spirit of tolerance and peaceful coexistence, equality, cosmopolitanism, the perfectibility of human nature, moral sensibility and responsibility, and the possibility of genuine progress. Humanists, in this sense, express profound confidence in human reason to understand nature and society without external mediation.

${ }^{4}$ Below $\S 5$ we treat David Hitchcock's adjustment to Johnson's notion of argumentation as manifest rationality.

${ }^{5}$ Consider also Hamblin's remark that "the logician ... is not a judge or a court of appeal, and there is no such judge or court: he is, at best, a trained advocate. It follows that it is not the logician's particular job to declare the truth of any statement, or the validity of any argument" (Hamblin 1993: 244; emphasis added).

${ }^{6}$ Our representation of informal logic and argumentation theory derives from a variety of sources, notably from informal logic textbooks, collections of essays, and from recent monographs. See references.

${ }^{7}$ Consider also: "Objectivity, as it relates to argumentation, must be reconsidered and reinterpreted if it is to have meaning in a conception that does not allow the separation of an assertion from the person who makes it" (1969: 59). "In modern logic, the product of reflection on mathematical reasoning, the formal systems are no longer related to any rational evidence whatever. ... The search for unquestionable univocity has even led the formalistic logicians to construct systems in which no attention is paid to the meaning of the expressions" (Perelman 1969: 13).

${ }^{8}$ Consider also: "Historically, the enthronement of mathematical rationality was just one aspect of a broader intellectual response to the loss of theological consensus following Luther's and Calvin's success in enrolling craftsmen and other members of the newly literate laity into Protestant congregations" (Toulmin 2001: 205).

${ }^{9}$ And in this connection, he also remarks: "However, there is also more to be said against the alethic criteria and in favour of a set based on acceptability or acceptance rather than truth.... we should consider, also, the case in which someone, with good reason, accepts a given set of premises and a given inference-process, and becomes convinced of a consequent conclusion [outside of making a quasi-moral judgment]. ... but, if we are to draw the line anywhere [respecting relevance of 'to whom'], acceptance by the person the argument is aimed at - the person for whom the argument is an argument - is the appropriate basis of a set of criteria [for argument appraisal]". (Hamblin 1993: 241-242)

${ }^{10}$ We might, of course, append this document with the first amendment of the Constitution of the United States of America \% "Congress shall make no law respecting an establishment of religion, or prohibiting the free exercise thereof; or abridging the freedom of speech, or of the press; or the right of the people peaceably to assemble, and to petition the Government for a redress of grievances".

${ }^{11}$ We can easily grasp that argumentation logicians naturally found inspiration in legal courtroom discourse and then reinvested considerable interest in dialectic and fallacious argumentation.

${ }^{12}$ Walton had already treated four kinds of procedural rules — namely, locution rules, commitment rules, dialogue rules, and win-loss rules — in connection with his CB persuasion dialogue (1984:131137). Walton and Krabbe also believe that their treatment of commitment is not psychological but pragmatic and critical (1995: 12). They treat systems of dialogue rules in chapter 4, which is an especially technical, one might say, a formal, treatment of dialogue reminiscent of the tack of traditional formal logic. They treat rules for two kinds of persuasion dialogue: permissive persuasion dialogue [PPD] and rigorous persuasion dialogue [RPD]. See Walton and Krabbe 1995: 133-161. 
${ }^{13}$ Johnson lists some pragmatic rules for the argumentation process (2000: 210); we use Hitchcock's discussion to reflect Johnson's thinking.

${ }^{14}$ Hitchcock revises Johnson's notion of argument (cited above $§ 1$ ) as follows: "An argument is a spoken discourse or written text whose author (the arguer) seeks to persuade an intended audience or readership (the Other or the Others) to accept a thesis by producing reasons in support of it. In addition to this illative core, an argument possesses a dialectical tier in which the arguer discharges his dialectical obligations" (2002:5). His revised definition of argumentation follows: "An argumentative discussion is a sociocultural activity of constructing, presenting, interpreting, criticizing, and revising arguments for the purpose of reaching a shared rationally supported position on some issue" (2002:8).

${ }^{15}$ Hitchcock notes that these derivations are non-mathematical in that they (1) depend upon implicit assumptions, (2) involve non-conclusive inferences, and (3) "are subject to the sort of criticism and future revision which Johnson [and argumentation theorists from Perelman, Toulmin, Hamblin on] regards as central to an argumentation discussion" (2002:12).

${ }^{16}$ Consider also in this connection the following passage: "A responsible, respectful, and reasonably efficient way to do so [i.e., consider diverse claims] is to thoughtfully consider relevant evidence and reasons, discuss the acceptability, relevance, and sufficiency of points with others, try to determine which claims are cogently supported, and do our best to address alternative positions and objections to them" (Govier 1999: 56).

${ }^{17}$ Interestingly, we find a number of argumentation theorists, such as Perelman, Tindale, Govier, Johnson, among others, to embrace kantian notions. Indeed, a kantian vacillation seems characteristic of argumentation theory (cf. Boger 2005b).

\section{References}

Barth, E.M. \& Eric C.W. Krabbe. 1982. From Axiom to Dialogue: A Philosophical Study of Logics and Argumentation. Berlin: Walter de Gruyer.

Blair, J. Anthony, Ralph H. Johnson (Eds.). 1980. Informal Logic: The First International Symposium. Point Ryes, CA: Edgepress.

Boger, George. 2003a. "A possible rapprochement of informal logic with formal logic." In J. Anthony Blair, Daniel Farr, Hans V. Hansen, Ralph H. Johnson, Christopher W. Tindale (eds.), Informal Logic at 25: Proceedings of the Windsor Conference. Windsor, ON: CD ROM.

Boger, George. 2003b. "Formal logic's contribution to the study of fallacies." In Frans H. van Eemeren, J. Anthony Blair, Charles A. Willard and A. Francisca Snoeck Henkemans (eds.), Proceedings of the Fifth Conference of the International Society for the Study of Argumentation, pp. 133-137. Amsterdam: SicSat.

Boger, George. 2005a. "Mistakes in reasoning about argumentation." In Kent Peacock and Andrew Irvine (eds.), Mistakes of Reason: Essays in Honour of John Woods, pp. 702-742. Toronto: University of Toronto Press.

Boger, George. 2005b. "Subordinating truth—is acceptability acceptable?" .Argumentation 19:2, 187-238.

Corcoran, John. 1989. “Argumentations and logic.” Argumentation 3, 17-43.

Eemeren, Frans H. van (Ed.). 2002. Advances in Pragma-Dialectics. Amsterdam: SicSat.

Eemeren, Frans H. van, Rob Grootendorst. 1992. Argumentation, Communication, and Fallacies: A Pragma-Dialectical Perspective. Hillsdale, NJ: Lawrence Erlbaum Associates. 
Eemeren, Frans H. van, Rob Grootendorst. 1995. "Perelman and the fallacies." Philosophy and Rhetoric 28, 122-33.

Eemeren, Frans H. van, Rob Grootendorst, Francisca Snoeck Henkemans, et al. (Eds.). 1996. Fundamentals of Argumentation Theory: A Handbook of Historical Backgrounds and Contemporary Developments. Mahwah, NJ: Lawrence Erlbaum Associates.

Eemeren, Frans H, van Rob Grootendorst, J. Anthony Blair, Charles A. Willard (Eds.). 1987. Argumentation: Analysis and Practices. Dordrecht: Foris Publications.

Eemeren, Frans H. van, J. Anthony Blair, Charles A. Willard, A. Francisca Snoeck Henkemans (Eds.). 2002. Proceedings of the Fifth Conference of the International Society for the Study of Argumentation.Amsterdam: SicSat.

Eemeren, Frans H. van, J. Anthony Blair, \& Charles A. Willard, A. Francisca Snoeck Henkemans (Eds.). 2003. Anyone Who Has a View: Theoretical Contributions to the Study of Argumentation. Dordrecht: Kluwer.

Fogelin, Robert J. and Walter Sinnott-Armstrong. 1997. Understanding Arguments: An Introduction to Informal Logic, $5^{\text {th }}$ ed. Fort Worth, TX: Harcourt Brace \& Company.

Freeman, James B. 1993. Thinking Logically: Basic Concepts for Reasoning. Englewood Cliffs, NJ: Prentice-Hall, Inc.

Freeman, James B. 1994. "The place of informal logic in logic." In R.H. Johnson and J. A. Blair (eds.), New Essays in Informal Logic, pp. 36-49. Windsor, ON: Informal Logic.

Govier, Trudy. 1987. Problems in Argument Analysis and Evaluation. Dordrecht: Foris Publications.

Govier, Trudy. 1988. A Practical Study of Argument, $2^{\text {nd }}$ ed. Belmont, CA: Wadsworth Publishing Co.

Govier, Trudy. 1999. The Philosophy of Argument. Newport News, VA: Vale Press.

Little, J. Frederick, Leo A. Groarke and Christopher W. Tindale. 1989. Good Reasoning Matters!, $1^{\text {st }}$ ed. Toronto: McClelland \& Stewart.

Hamblin, C.L. 1993. Fallacies. Newport News, VA: Vale Press.

Hansen, Hans V. and Robert C. Pinto (Eds.). 1995. Fallacies: Classical and Contemporary Readings. University Park, PA: The Pennsylvania State University Press.

Hitchcock, David. 1983. Critical Thinking: A Guide to Evaluating Information. Toronto: Metheun.

Hitchcock, David. 2000. "The significance of informal logic for philosophy." Informal Logic 20:2, 129-138.

Hitchcock, David. 2002. "The practice of argumentative discussion." Argumentation 16, 287-298.

Hitchcock, David: 2003. "Informal logic 25 years later.” In J. Anthony Blair, Daniel Farr, Hans V. Hansen, Ralph H. Johnson, Christopher W. Tindale (eds.), Informal Logic at 25: Proceedings of the Windsor Conference. Windsor, ON: CD ROM.

Johnson, Ralph H. 1996. The Rise of Informal Logic. Newport News, VA: Vale Press.

Johnson, Ralph H. 1999. "The relation between formal and informal logic." Argumentation 13:265-274.

Johnson, Ralph H. 2000b. Manifest Rationality: A Pragmatic Theory of Argument.

Mahwah, NJ: Lawrence Erlbaum Associates. 
Johnson, Ralph H. 2003. "Commentary on C. Tindale's 'The Truth about Orangutans: Defending Acceptability'.” In J. Anthony Blair, Daniel Farr, Hans V. Hansen, Ralph H. Johnson and Christopher W. Tindale (eds.), Informal Logic at 25: Proceedings of the Windsor Conference. Windsor, ON: CD ROM.

Johnson, Ralph H. and J. Anthony Blair. 1977. Logical Self Defense, $1^{\text {st }}$ ed. Toronto. McGraw-Hill Ryerson.

Johnson, Ralph H. and J. Anthony Blair. 1980a. "Informal logic: Past and present." In J. Anthony Blair and Ralph H. Johnson (eds.), Informal Logic: The First International Symposium, pp. 1-19. Point Reyes, CA: Edgepress.

Johnson, Ralph H. and J. Anthony Blair. 1980b. "Introduction.” In J. Anthony Blair and Ralph H. Johnson (eds.), Informal Logic: The First International Symposium, pp. ix-xvi. Point Reyes, CA: Edgepress.

Johnson, Ralph H. and J. Anthony Blair. 1980c. "The recent development of informal logic.” In J. Anthony Blair and Ralph H. Johnson (eds.), Informal Logic: The First International Symposium, pp. 3-28. Point Reyes, CA: Edgepress.

Johnson, Ralph H. and J. Anthony Blair (Eds.). 1994. New Essays in Informal Logic. Windsor, ON: Informal Logic.

Johnson, Ralph H. and J. Anthony Blair. 2000a. "Informal logic: An overview." Informal Logic 20.2, 93-107.

Kahane, Howard and Nancy M. Cavender. 1998. Logic and Contemporary Rhetoric: The Use of Reason in Everyday Life, $8^{\text {th }}$ ed. Belmont, CA: Wadsworth Publishing Co. Levi, Don. S. 2000. In Defense of Informal Logic. Dordrecht: Kluwer.

Perelman, Chaïm. 1967. Justice. New York: Random House.

Perelman, Chaïm. 1979. The New Rhetoric and the Humanities: Essays on Rhetoric and its Application. Dordrecht: D. Reidel Publishing Company.

Perelman, Chaïm. 1980. Justice, Law, and Argument: Essays on Moral and Legal Reasoning. Dordrecht: D. Reidel Publishing Company.

Perelman, Chaïm. 1982. The Realm of Rhetoric. Notre Dame, IN: University of Notre Dame Press.

Perelman, Chaïm. 1989. "The new rhetoric and the rhetoricians: remembrances and comment." In Dearin, Ray D. (ed.), The New Rhetoric of Chaim Perelman: Statement \& Response, pp. 239-251. Dordrecht: Klumer.

Perelman, Chaïm and L. Olbrechts-Tyteca. 1969. The New Rhetoric: A Treatise on Argumentation. Notre Dame, IN: University of Notre Dame Press.

Pinto, Robert C. 2001. Argument, Inference and Dialectic: Collected Papers on Informal Logic. Dordrecht: Kluwer.

Scriven, Michael. 1976. Reasoning. New York: McGraw-Hill.

Scriven, Michael. 1980. "The philosophical and pragmatic significance of informal logic." In J. Anthony Blair and Ralph H. Johnson (eds.), Informal Logic: The First International Symposium, pp. 147-160. Point Reyes, CA: Edgepress.

Siegel, Harvey and John Biro. 1997. 'Epistemic normativity, argumentation, and fallacies', Argumentation 11, 277-292.

Tindale, Christopher W.: 1994, "Contextual relevance in argumentation." In Ralph H. Johnson and J. Anthony Blair (eds.), New Essays in Informal Logic, pp. 67-81. Windsor, ON: Informal Logic. 
Tindale, Christopher W. 1999. Acts of Arguing: A Rhetorical Model of Argument. Albany, NY: State University of New York Press.

Tindale, Christopher W. 2003. "The Truth about Orangutans: Defending Acceptability." In J. Anthony Blair, Daniel Farr, Hans V. Hansen, Ralph H. Johnson and Christopher W. Tindale (eds.), Informal Logic at 25: Proceedings of the Windsor Conference. Windsor, ON: CD ROM.

Toulmin, Stephen E. 1958. The Uses of Argument. Cambridge: Cambridge University Press.

Toulmin, Stephen E. 1972. Human Understanding. Princeton: Princeton University Press. Toulmin, Stephen E. 2001. Return to Reason. Cambridge, MA: Harvard University Press. Toulmin, Stephen, Richard Rieke and Allan Janik. 1979. An Introduction to Reasoning, New York: Macmillan Publishing Co.

Walton, Douglas N. 1982. Topical Relevance in Argumentation. Amsterdam: John Benjamins Publishing Co.

Walton, Douglas N. 1987. Informal Fallacies: Towards a Theory of Argument Criticism. Amsterdam: John Benjamins Publishing Co.

Walton, Douglas N. 1989. Informal Logic: A Handbook for Critical Argumentation. Cambridge: Cambridge University Press.

Walton, Douglas N. 1992. The Place of Emotion in Argument. University Park, PA: Pennsylvania State University Press.

Walton, Douglas N. and Erik C. W. Krabbe. 1995. Commitment in Dialogue: Basic Concepts of Interpersonal Reasoning. Albany, NY: SUNY Press.

Walton, Douglas and Alan Brinton (Eds.). 1997. Historical Foundations of Informal Logic. Brookfield, VT: Ashgate Publishing Company.

Willard, Charles A. 1989. A Theory of Argumentation. Tuscaloosa, AL: The University of Alabama Press.

Woods, John. 1980. "What is informal logic?” In J. Anthony Blair and Ralph H. Johnson (eds.), Informal Logic: The First International Symposium, pp. 57-68. Point Reyes, CA: Edgepress.

Woods, John. 1989. "The necessity of formalism in informal logic." Argumentation 3, 149-167.

Woods, John. 2000. "How philosophical is informal logic?" Informal Logic 20:2, 139167.

George Boger Department of Philosophy

Churchill Tower 716

Canisius College 2001 Main Street

Buffalo, NY 14208-1098

boger@canisius.edu 